\title{
THE IMPORTANCE OF EXPERIMENTATION IN THE TEACHING OF SCIENCES TO ELEMENTARY SCHOOL
}

\author{
Brasilia Castelhano Soares, Maria Eduarda Castelhano de Campos, Jean Rodrigo \\ Thomaz, Geovana da Cruz Pereira, Rafael Roehrs \\ Grupo Interdisciplinar de Pesquisa em Prática de Ensino (GIPPE), Universidade Federal do Pampa \\ (UNIPAMPA), Uruguaiana, RS, Brazil
}

\begin{abstract}
RESUMO
A experimentação, principalmente se comunicativa, é importante fator contribuinte para o interesse e a aprendizagem significativa em Ciências. Deste modo, o presente trabalho reconhece a importância da inserção da experimentação de maneira problematizadora no ensino de Ciências no nível fundamental, bem como realiza uma revisão sobre o assunto utilizando-se de artigos, leis, parâmetros e programas nacionais, e como os mesmos referemse ao Livro Didático e ensino fundamental ligados à experimentação. Com isto, mostrou-se que o ensino de Ciências nas escolas teve sempre o papel de reprodução de informações incontestáveis, onde a experimentação nem sempre tem sido aplicada de maneira que os estudantes construíssem seu conhecimento ao lado do professor. Entende-se ser necessária uma mudança por parte de todos, para que as escolas recebam atenção de verbas e que a formação dos professores os preparem para inserir a experimentação do melhor modo aos alunos.
\end{abstract}

Palavras-chave: Problematização. Educação. Prática.

\begin{abstract}
The experimentation (especially the communicative one) is an important contributing factor for the interest and meaningful learning of science. Therefore, this study recognizes the importance of inserting experimentation in a problematical way in science education at the elementary school, as well as perform a review on the subject using articles, laws, and national programs and parameters, as well as these resources relate to the Textbook and basic Education regarding to experimentation. Thereby, it has been shown that the teaching of science in schools has had the role of reproducing undisputed pieces of information, thus experimentation has not been applied in a way in which students would be able to build their knowledge along with the teacher. It is needed a change by everyone, so that schools may receive fund and teacher training processes would prepare teachers to introduce the experimentation in a better way to students.
\end{abstract}

Keywords: Problematization. Education. Practice. 


\section{INTRODUCTION}

Agostini and Delizoicov (2008) affirm that in the 1930s, the creation of Brazilian universities stimulated the scientific production and the formation of a community of scientists and teachers, what resulted in the approximation between teacher training programs and bachelor degrees. This approach is fundamental to the improvement of science teaching and the insertion of experimental teaching in schools.

Wanderley (2007) states that:

The students' lack of interest is due to the way in which teaching is transmitted, in a way that concepts are taught using theory only. What for most students is boring, being not applicable to various aspects of everyday life, then being something considered just to be memorized.

Therefore, this paper aims to recognize the relevance of discussing the subject experimentation, as well as its insertion in the teaching of sciences.

Students of teacher training majors need to recognize and know how to use alternative teaching practices to reduce learning difficulties for students. If there is not adequate training during teacher training period to deal with experimentation, and if in the school there is not infrastructure of high standard to the student's practice, so that the student will not be fully proficient in learning the contents. Justifying the fear and often resistance of the teacher to perform experimental activities using reagents in inappropriate places, without security and appropriate spaces. In case of practical activities in which there is no risks to students, there is an opportunity to apply them in the classroom, but the environment is not appropriate.

It has been noticed the existence of a set of factors which hinder the learning of science teaching; not only teachers being responsible, but also a students' lack of interest, a lack of laboratories, overcrowded classrooms, school infrastructure, among many other factors. In order to change this situation, it is indispensable that the teachers be continuously though the learning process to provide news in their classes, arousing motivation and seeking students' interest, applying theory and practice, so that the students have a better assimilation of the content, relating them to their daily life.

It is of great importance the awareness of science teachers that experimentation arouses interest among students in various levels of learning. Students attribute to experimentation a motivating character. It is common to hear from teachers the affirmation that the experimentation increases the learning ability, working as a way to involve the student to the topics addressed during theoretical classes. 


\section{EXPERIMENTATION IN ELEMENTARY SCHOOL ACCORDING TO “LDB”}

According to the National Educational Bases and Guidelines Law (LDB/1961), since its promulgation, elementary education is compulsory and free in public schools, lasting nine years (starting at the age of six). The law determines that the goal of elementary education is the basic education of the citizen through the development of understanding and learning.

Santana (2011) certifies that, nowadays, with innumerable innovations emerging almost instantaneously in scientific and technological areas, "knowledge becomes a determinant and indispensable factor, whether for the inclusion of man at work or for the understanding of oneself and the phenomena of nature". Based on these circumstances, NCPs propose,

[...] school has a fundamental role on forming capable and conscious citizens who understand the environment in which they live in and who are capable of criticizing and making decisions socially meaningful, legitimizing their opinions. The lack of such knowledge may create difficulties on positioning themselves correctly on the important decisions that will involve themselves in the future.

According to the National Curriculum Parameters (PNCs/1998), until the promulgation of the LDB, "[...] the school scene was dominated by the traditional education, although renewal efforts were in process ...". The Natural Science classes were applied,

[...] only in the last two grades of the old junior high school. This law extended the compulsory teaching of the subject to all junior high schools, but only from 1971, with Law no. 5,692, Sciences became compulsory in the eight grades of the elementary schools. (PNCs, 1998, p.19)

Susi (2011) describes that the model of curriculum applied in teacher training for science teaching was the short one, being modified later, so the "scientific degrees become full in one of the areas of the sciences." This statement reveals to be recent the insertion of the natural sciences in elementary school, starting from the short form in which teachers would be formed with a basic knowledge in science. Subsequently, this knowledge was deepened and specialized in specific areas of science, in order to raise the quality of teaching and learning in schools.

To Susi (2011), "however, today the teaching of science has insufficient results, leading us to consider that one of the problems is linked to the model of teacher training, ranging from disciplinary specificity to generality".

Difficulties in the application of an experimental method in the classroom may be related to the precarious formation of teachers. Bizzo $(2000 ;$ p.6) does not consider the associate's degree a major but "a mere training". 
To Guimarães (2009),

[...] many criticisms of traditional teaching may refer to the passive action of the learner who is often treated as a mere listener of the information which the teacher exposes. Such information, almost always, is not related to the previous knowledge that students have built throughout their lives. And when there is no relation between what the student already knows and what they are learning, the learning process is not meaningful.

Silva et. Al. Express (2009 p.2),

We understand once experimentation is developed along with contextualization, which takes into accounting socio-cultural and economic aspects of the student's life, the learning outcomes may be more effective.

Possibly, with the occurrence of a non-significant learning, the existence of a science discipline focused essentially on elementary education may be of great importance. Therefore, with an experimentation dedicated to the fundamental level, students will be provided with a better and more concrete base in science education as an attempt to introduce students to experimentation in natural sciences, providing interest to remain from elementary to higher education.

To Oliveira et.al. (2005),

[...] in general, applying an experiment that encourages logical thinking (a game, a play or even the use of comics in classroom) [methods that are beyond the traditional and formal education, so that makes teaching and learning less monotonous to attract students' attention], brings a great incentive to science education.

The National Curriculum Guidelines attests that "[...] in the school environment, scientific knowledge was considered a neutral, exempt knowledge, and the scientific truth was taken for granted [...]". "It is a consensus that experimentation is a fundamental activity in the teaching of science" (Galiazzi, et.al., 2001, p.250). As soon as experimentation was inserted into school environment, much criticism has been said about the consequences. Therefore, according to the NCPs (1998), suggestions for amendment to teaching of Natural Sciences there has been guided by the need of the curriculum respond to "advancement of scientific 
knowledge and pedagogical demands generated by the influence of the movement called New School."

Since the concern to develop practical activities gained a marked presence in the teaching projects and on the degrees of teacher training, several didactic materials relating to that were produced. The fundamental objective of the teaching of natural sciences was to make the student to experience what is called the scientific method (observe, hypothesize, test the hypotheses, refute and abandon them when appropriate), attempting to rediscover knowledge.

The rediscovery method, with its emphasis on the scientific method, for a long time has followed the objectives of the teaching of Natural Sciences, causing some teachers to inadvertently identify scientific methodology to the methodology of the teaching of Natural Sciences, missing the opportunity to work with students the processes of investigation adapted to the conditions of the learning and open to questions of distinct nature from those of strictly scientific interest, in a way with greater amplitude and varieties. (PNCs, 1998, p.20)

According to Guimarães (2009), the perspective that the results obtained from the experimentation are a response to the questions raised by the students when they interact with the subject to be worked with, should not be applied in the experimental classes as an exact methodology, in which learners are guided with a script and must achieve the goals the teacher expects. Such a method means that there is no problem to be solved.

If the teacher launches an experiment, expecting the students to arrive at the expected result, without encountering differences during the process, and without a reflection on what was done wrongly, this teacher will not be making the best use of experimentation in the science teaching. This process of experimental activity, in which the answer to the problem proposed by the teacher is found as in a cake recipe, has its importance. Therefore, expository experimentation is important for discussion with students in simpler classes, however, there are innumerable ways to apply experimentation in which the student participates in the process of constructing the activity.

It is necessary that students and teachers learn to participate in research throughout the process, to learn how to make decisions, to be placed in situations that contrast their conceptions about the construction of knowledge, generally considered as a linear process, without stumbling and errors (GALIAZZI , Et al., 2001, p.251) 
Mayer et al. (2013) include that "it is necessary that science education be directly linked with the world of students, that is, they can come to draw from the school science and apply in their daily lives."

Silva et al. (2009) acknowledge that experimental activities should be seen as one of the tools of science discourse and as such should be included in the classroom environment in order to allow the enculturation of students and teachers. This states that students should learn not only theories of science, but also how to construct scientific knowledge in a process of questioning, discussion of arguments and validation of these arguments through oral and written dialogues, with an argumentative community that begins in classrooms, but transcends them. Silva apud Lima et al. (2007) say that demonstrative experiments help to focus student's attention on the behaviors and properties of the materials used, such as chemical substances. In this way, the implementation and interpretation of experiments contribute to the construction of chemical concepts by the students.

Galiazzi et al. (2001) also argue that although many teachers believe that they can transform science teaching through experimentation, experimental activities are infrequent in schools, under the justification of the lack of laboratories, and those which have them, do not have the resources to maintain them.

On the use of the laboratory for experimental activities, Santana (2011) states that this does not guarantee the best learning, arguing that to be effective it depends on the way it is used. The author also mentions that for this, it is necessary for the teachers to be qualified and able to work with the students the question of the practical activity.

\section{REVIEW ABOUT THE EXPERIMENTATION IN FUNDAMENTAL EDUCATION ACCORDING TO “LDB"}

According to Mortimer (1996, p. 5), "learning science involves the initiation of students into a new way of thinking and explaining the natural world, which is fundamentally different from those available in the common sense." For this reason, possibly, for Carvalho et.al. practical work has unquestionable importance in science and, according to the author, "should occupy a central place in your education."

Rosito (2008) further intensifies that

The experimentation is essential for science teaching because it allows the practical activities to integrate teacher and students, to provide a joint planning (in which teacher and student construct the process of the activity) and the use of teaching techniques that can lead to a better understanding of the science processes. 
According to the author, "Science teachers consider experimental activities important to a good school, but there is no consensus about the goals on experimentation."

Santos (2014) provides the most important functions of the experimentation, where are: raise and maintain student's interest involving them in scientific research; develop problem solving skills; understand the basic concepts needed; and develop skills.

To Oliveira et. Al. (2005),

[...] experimentation allows students to manipulate objects and ideas and negotiate meanings between themselves and with the teacher during the lesson. It is important that the practical classes be conducted in a pleasant way so that they do not become a competition between the groups, but an exchange of ideas and concepts when the results are discussed.

The importance of experimentation in science teaching has been cited numerous times during the second half of the twentieth century. The Brazilian school system always had a traditional pedagogy, which cooperated so that the teaching of science was seen as a process where only scientific truths were transmitted, with no chance of discussions about the contradictions present in the process of scientific production.

Although the teaching of science in basic education is fundamental, unfortunately, the lack of differentiated classes is noticeable, seeking the interest of students through the disadvantage of the predominance of traditional classes. However, the disorganized practice of these classes is more detrimental than the absence of these classes, which does not allow the student to understand the facts or to develop logical reasoning.

Experimentation and, in particular, the conduction of its application in the school curriculum, has been much discussed by researchers in the area of science education.

The incentive to use experimentation emerged as a national project after the creation of the Brazilian Institute of Science and Culture (IBECC) in 1946, and started the production of curricular materials with proposals for laboratory practices for students and teachers (MARANDINO; SELLES; FERREIRA, 2009).

Many science teachers and authors of the area consider experimentation as a possible source for the discovery of new knowledge, which demonstrates the visualization of theoretical concepts present in textbooks and awakens students' curiosity, thus contributing to the teaching and learning process.

Experimentation is a rich activity to obtain scientific information, because through it there is the realization of a natural phenomenon. The student has the possibility of accompanying and investigating this phenomenon and its transformations (BRASIL, 1997). 
Hodson (1994) warns that experimental teaching should be accompanied by reflection. Amaral and Silva (2000) maintain this idea and point out the need to create classroom spaces that allow the dialogue between theory and experiment. Mortimer et al. (2000) argue that it is of no use for the teacher to develop practical activities in the classroom if, subsequently, in this environment, the moment of the theoretical-practical discussion - that transcends the phenomenological level knowledge and the common knowledge of the students - is not given.

Azevedo (2003) agrees that the way in which experimentation can be approached and the benefits that practical lessons provide require some teacher skills, who should select how their teaching project will be executed. It is extremely important that the objectives of your project are clear, and that the teacher not only master the content, but also argue and question, guiding the teaching process.

As discussed by Azevedo, it is also extremely important that such means of employing experimentation in lesson plans should be inserted into the teacher training itself. Once, many times, teachers complete their formation admitting deficiency in basic points.

As for the various factors limiting the use of experimentation in didactics, Pereira (2010) argues that sometimes the problem is not only found in the didactics of the teacher, but also in the lack of conditions to work experimentation, being the number of students per class really excessive. There is also a shortage of infrastructure and especially reduced working hours.

\section{EXPERIMENTATION IN THE FUNDAMENTAL TEXTBOOK (TB): THE CHILDREN'S LEARNING PROCESS AND ITS IMPORTANCE}

To Stella Marega (2014), in his paper "The Children Development and Learning in Early Childhood Education, The Playful", the movement and plays are fundamental in the development and learning processes of children in kindergarten. Once it is through those processes that the children create conditions "to develop their skills, form concepts, create their hypotheses, select ideas, establish logical relationships, integrate perceptions and socialize." For the author, the use of recreational activities and concrete materials is fully related to a "child's cognitive development."

According to the author, Piaget states that children learn constructing and reconstructing their thinking, by the assimilation and accommodation of its structures. Such thought construction is determined by Piaget as Sensorimotor Stage, Symbolic Stage and Conceptual Stage.

To him, the first stage, which reaches the age of zero to two years, is the one in which the development of motor coordination begins, the child already begins to differentiate the objects from his own body and his thoughts are linked to the concrete. In the second, (the symbolic, reaching the ages from two to seven years), Piaget realizes that the children's thinking is centered on themselves as a self-centered thinking. Marrega ensures this idea, concluding 
that it "is at this stage that the language is taken as socialization, which is given through speech, drawings and drama".

The last stage, called the Conceptual, reaches age seven to eleven. On it, to the author, Piaget states that the child remains egocentric, yet with limited empathy ${ }^{1}$. Marega concludes by reaffirming that it is through the playfulness that the child expresses his "true self." Still, Piaget calls the role of the teacher as indisputably decisive for the process of teaching learning, and it is his the task of intervening and stimulating, serving as a support for the students' self-esteem.

To Araújo and colleagues (2008), Vygotsky (1991) points out that "children start their learning before they enter school, exactly the learning of spontaneous concepts." In this way, the authors conclude that a learning situation already has previous history, then the children already have their first hypotheses about the contents to be worked. So to Vygotsky, "learning and development are interrelated from the first day of the life of the subjects."

Araujo and colleagues point out, based on Vygotsky, that only "a good learning promotes development and that good teaching is the one that presents a forwardlooking orientation." This orientation is directed to what the student is only able to do with the aid of a more experienced one.

Good teaching is what relates scientific concepts (concepts constructed in a formal learning situation) to spontaneous concepts (concepts constructed in everyday situations) and helps the student to internalize scientific concepts in a spiral movement, in which he learns new concepts and, thus, evolve. (ARAÚJO et al., 2008, p.04)

The way knowledge is understood by students may even depend on their interests on the subject studied, but it may also depend on how the teacher approaches the subject. Taha and Pinheiro (2009) agree that,

The teacher should always seek a set of diversified actions to disquiet his student, instigate his curiosity and make him have an interest in satisfying this curiosity. [Making it clear that one of these actions can be experimentation] (emphasis added).

Nowadays, although the technology predominates many spaces dedicated to the teaching of science, such as experimental kits, computer programs, videos among others, for Maia and Villani "TB is still the most widely used teaching tool and the one which more guides teachers". Many authors like Echeverría, Mello and Gauche (2010) and Maia et al., (2011), point out that "the TB is characterized as a work of reference for teaching and an almost exclusive source of sound scientific information for students", also affirming that the textbook is

\footnotetext{
${ }^{1}$ Empathy: psychological ability to feel what another person would feel. Hoffman (1981) defines it as "an appropriate emotional response to another person's situation."
} 
a tool permeated by power relations, being modified throughout time, with the cultural, historical, political and economic contexts of society.

The contribution of the textbook so that the teacher provides a meaningful learning is included in their teaching practices, remembering that they need to be in constant updates. A textbook containing lots of information, but mostly outdated, does not fully support a meaningful understanding to students. For, in addition to containing information already outdated, facing a high index of use of advanced technologies, the students themselves can often search, through computers and cell phones, the information contained on the textbooks, to a better understanding of the contents, and prove that the content of the books is no longer current, which may contribute to a lack of confidence in the use of textbooks.

"The textbook is one of the most used materials in teaching science, since it guides the practice of teaching, from the choice of content to the evaluation process" (MAIA and VILLANI, 2016). Such a resource is still widely used in schools and determines the ways in which teaching is worked. Geraldi (1993: 226) reaffirms this idea, pointing out that it is the textbook that gives direction to the pedagogical process, since the content contained in it is often the school content of the curriculum in action.

This idea is also corroborated by Ossak and Bellini (2009), when they discuss the fact that the teacher is imprisoned to use the textbook, making the pedagogical process (the content and the way of teaching it) depending only of it. Güllich and Silva (2013) state that "this force that the textbook has in the educational process is old. In several sources it may be found the idea that the official curriculum to be taught is on the books."

The authors also say that,

The need to analyze the role of the textbook and its interference in teaching science [since the analysis may favor a critique of traditional modes of teaching and allow future teachers to be more prepared to distrust the textbook], is concomitant to the process of deconstruction of the veiled images which the textbook brings and of the role that it possesses as the holder of truths and of the correct and pure science.

It can be seen that the action of total reliability in the textbook and the view of unquestionable and always true held by teachers can cause students' disinterest and non-significant learning. It is known that it is very difficult to teach, especially if the situation is completely lacking in students' interest. It requires the flexibility of teachers, not only to interpret the experimentation presented by the TB, but also to take it to the classroom, applying it in a dynamic and reflexive way. Maia and Villani further contribute to the conclusion about TB as undeniable:

Thus, although TB is an exciting teaching resource for the teacher, giving it a sense of security, on the other hand, it can make it into an "easy" routine, to the point of preventing or at least hindering the 
exercise of their autonomy and creativity [...] In this sense, the most comfortable position would be for the teacher to create his own style of conducting the lesson, without necessarily limiting himself to the mere reproduction and sequences proposed by the TB (MAIA and VILLANI, 122- 123, 2016).

Taha and Pinheiro (2009), when analyzing different seventh grade textbooks, conclude that books, like many others, confirm the importance of TB in the teachers' base for the preparation of their classes. Experimentation is not the main focus of the textbooks and the contextualization indicated by NCPs is little emphasized in the subjects it offers.

To complement, we can cite Silva (2014), who states:

The National Textbook Program created in 1985 aims to ensure that books adopted by the public school system meet the requirements of official documents such as National Curriculum Parameters (NCP) and the National Educational Bases and Guidelines Law (LDB / 96)

Silva (2014) still mentions Del Pozzo (2010), who analyzed the way in which experimental activities by the 2010 PNLD are evaluated, present in the didactic collections of Sciences. Alleging most of the time, they do not emphasize problematization and research, neither stimulate students' cognitive development.

\section{THE IMPORTANCE OF EXPERIMENTATION AND THE FACTORS THAT LIMIT ITS APPROACH IN THE TEACHING-LEARNING PROCESS}

To Santana (2011) the practical classes favor for the student to understand not only the phenomena of science but also how it develops, making the class become less complex and closer to the student's reality. According to Pereira (2010) "The use of experimentation as an aid to develop the understanding of concepts is of great importance, once it leads the students to participate in their learning process".

There are numerous factors that limit the application of practical activities in schools, one of them being the high rate of lack of infrastructure in public schools. In Brazil, according to Neto et al. (2013), which included data from the 2011 School Census (194,932 schools), only $0.6 \%$ of schools have an infrastructure close to the ideal for education (consisting of: library, computer lab, science laboratory, sports court and adequate facilities to attend students with basic needs). And $44 \%$ only have piped water, toilets, electricity, sewage and kitchen. The authors state that they expected the results to show the precariousness of many Brazilian schools, but that the percentage of elementary $(44 \%)$ and advanced $(0.6 \%)$ was a "shock". 
We knew that we would find differences and that the rural area, for example, would have more deficient infrastructure. But we did not think it would be so much. The same applies to regional differences and to municipal networks, in which schools with the worst conditions are concentrated.

To Neto et al. (2013) it is still necessary to correlate the results of assessments of students' performance with the physical conditions of the schools.

No matter where the children are: they are entitled to a quality education. This also presupposes a school infrastructure quality. It requires more resources, with an investment to be realized efficiently.

It is understood that is not enough to know the importance of experimentation in classrooms and that the lack of infrastructure limits its use; It is needed the application of funds, investments to get efficient learning outcomes.

Santana (2011) also confirms that only the use of the laboratory for experimental activities does not guarantee better learning because their effectiveness depends on how it is used,

[...] in order the use of laboratories and experimentation to bring expected results as the teaching-learning process, it is needed qualified and able teachers to work with students by connecting theory to practice.

There are many criticisms regarding the lack of practical classes in science education. On the one hand there is a lack of financial incentives from public bodies, on the other hand it is needed to consider the teacher's attitude towards the difficulties encountered to implement the experimentation. In many cases, even the factors that limit the use of the practice should not cause the extinction of experimental activities. To Fagundes (2007),

The teacher should minimize these problems, finding alternative ways to conduct practical classes, using different materials and using internal and external spaces that the school has to make up for the absence of laboratory and use of equipment.

Regarding it, Borges (2002) argues that, 
[...] many schools have suitable places to conduct experimental activities such as laboratories or rooms intended for this, but most of the time these settings are not used. Among the reasons why we teachers are not prepared to carry out these activities and guide the students in the course of application, are lack of interest in using the same methodological alternatives and the time that would be lost on carrying out this type of class.

Regarding the teacher, the importance of investment is brought up again. While they require numerous improvements in schools, as well as the salaries of employees working in the institutions, it is urgently needed to invest in innovation during teacher training programs.

So Behrsin and Selles (2001), claim that

[...] improving the quality of education is not only dependent on the dedication and the teacher's own interest to perform satisfactorily its role in society. It is indispensable commitment by the government entities to provide education professionals decent working conditions and adequate exploitation in school spaces for qualified science education.

However, Gioppo, Scheffer and Neves (1998) argue that

[...] the practical activities do not require specialized facilities and equipment to be performed, as conventional science laboratories. They can develop these practices in classrooms with the use of experiments or activities, often simple. Including the use of materials that can be found and handled easily. The important thing is the end result and what the activity causes the students on the resolution of problem situations.

It is understood then that there must be a collaboration from both parties. Once it is the State's duty to provide a safe space and quality for the best teaching and learning of the students, as well as invest in teacher training (investment that should not be done only in academic but also on minimum wage, valuing the profession of educator). It is also the duty of the teacher to find ways to educate differently, opting for fun and experimentation, to convey the best knowledge to students. 


\section{FINAL CONSIDERATIONS}

As a first observation, the factors related to the use of hands-on activities in science education, discussed in this paper, are taken up: how the methodology of experimentation is addressed (if addressed) in textbooks of Sciences; the investment of funds in the infrastructure of Brazilian schools in order to create a quality environment for student learning; improving the training of science teachers, so that they enter into the labor market able to work optimally with the playfulness and experimentation, able to use improvisation and creativity in schools.

Therefore, it is also necessary to reaffirm that teachers need a better knowledge of the investigative role that experimentation provides, once experimentation is, in most cases, taken as a way to exemplify, illustrate or prove what is studied during the lecture. In order to deconstruct this vision, teachers need theoretical and practical training on the experimental values and the methods of implementing it on a day-to-day basis. They need to learn that the NCP's treat experimentation in an investigative and communicative way as a base to the proposed objectives for the teaching of science, indicated (aamong with observation) as a teaching strategy that helps building students' knowledge.

Once NCP's themselves bring criticism to a traditional and conservative education, in which the student used to reproduce what was presented in classroom, science was seen as indisputable and a practical activity was like a recipe to which the student used to follow the steps to get a single correct result without reflection. The National Educational Bases and Guidelines Law (LDB/1961) establishes a better science education in all grades of elementary school, even though presents a mere reproductive mode of experimentation. Leading to conclude, then, that if a traditional education is no longer appropriate as the best means of learning to students, its permanence in classroom eventually become detrimental to students and even to teachers, not providing a significant learning.

The experimentation that is done through an investigative, reflective and communicative way, combined with playfulness, not only provides the teacher a different way of teaching, but stimulate students to study and construct their own knowledge. Moreover, it has great potential for the formation of citizens who understand and value science and its contributions to students' daily routine.

Some authors support the idea of forming a stable body of Science teachers in each school, a situation in which teachers would compromise to make room for experimentation, making the practice receive more attention and support of school coordinators.

Thus " [...] it is formed a study and discussion space of practical activities in schools, encouraging the pursuit of material and financial support by the School Board, Education Board and the Department of Education [...]" ( ANDRADE and MASSABNI 2011, p.18).

When the practice involves students in all phases, including experimental planning and makes the use of decontextualized and reproductive experimentation to be questioned, "it becomes a learning moment full of thought and creation." It is finally understood that in order to 
build a teaching-learning of quality and good use, there must be a general cooperation of the school, students and government entities.

When there is the collection of the teachers by a qualified space to teach science; when students value the space and material that is provided to them; when government entities invest in the best way in academic and wage appreciation of teachers, it causes them to feel valued and encouraged to exercise their role as educators, obtaining better results in school performances.

Finally, improvements in the teaching of science, the insertion of the investigative mode of experimentation and training of qualified teachers are seen as necessary and extremely important for the quality of education.

\section{REFERENCES}

AGOSTINI; WW; Delizoicov, NC TRIAL TEACHING IN BASIC EDUCATION: IMPASSE AND CHALLENGES. National Meeting of Research in Science Education - VII Enpec - Florianopólis, 2009.

AMARAL, LR; SILVA, AC Practical work: teachers' conceptions of experimental classes in general chemistry disciplines. Evaluation notebooks, Belo Horizonte, v. 1, no. 3, p. 130-140, 2000.

ANDRADE, Marcelo Leandro Feitosa; Massabni, Vânia Galindo. The Development Practice Activities at School: A Challenge for Science Teachers. Science \& Education, v.17, n.4, 2011. ARAÚJO lived oak; Araujo, Rita de Cássia BF; SCHEFFER, Ana Maria Moraes. Discussing Learning and Development of Children in the light of the historical-cultural reference. Juiz de Fora, 2008.

AZEVEDO, Maria Cristina PS Education for research: questioning the activities in the classroom. In: OAK, Anna Maria Pessoa. Science Education: Bridging research and practice. São Paulo: A pioneer Thomson, 2003.

BARROS, Grace Thainá Encina.; LOMBA, Kathiellen Sousa; MEIRA, Ewerton Vinícius; CASTRO, David Tsuyoshi Hiramatsu of .; PEREIRA, Maria Fernanda Ramos; ANTUNES, Fabiano. The Science Teaching the practice of experimentation: a report of teaching experience. Mato Grosso do Sul: 2013.

BIZZO, N. Sciences: easy or difficult? Editora Attica, São Paulo. 2000.

BEHRSIN, Maria Cristina Doglio; SELLES, Sandra Escovedo. teaching continuing education: reflections from the voices of teachers participating in post graduation courses of ongoing science education. Proceedings of I ENEBIO. New millennium, new educational practices? P. 96-100. Niterói, 2001.

BRAZIL. Department of Elementary Education. national curriculum guidelines: Natural Sciences / Department of Elementary Education. Brasília: MEC / SEF, p. 138, 1998.

BORGES, AT New directions for the lab school science. Notebook Brazilian Physics Teaching, v. 19, no. 3,2002 
COHN, Clarice. Anthropology Child. 2.ed. Rio de Janeiro; Ed. Jorge Zahar, 2009.

DEL POZZO. L. The experimental activities in the ratings in textbooks PNLD Sciences 2010. Dissertation (Master of Education), State University of Campinas, Campinas, 2010.

FAGUNDES, Suzana Margarete Kurzmann. Experimentation in Science classes: a means for the formation of autonomy? In: Galiazzi, Mary C. et all. curricular constructivism network in science education: a survey door in the classroom. ljuí, Ed. Unijuí, p. 317-336, 2007.

GALIAZZI, Mary C. et all. curricular constructivism network in science education: a survey door in the classroom. ljuí, Ed. Unijuí, p. 317-336, 2007.

GERALDI, Corinta Maria Grisolia. Production of teaching and research in education: study on the teaching in the course of pedagogy. Campinas: [Sn], (Ph.D. Thesis, Campinas) 1993.

GIOPPO, C .; Scheffer EWO; NEVES, MCD The experimental teaching in elementary school: A case of reflection in Parana. Educate, n. 14, p. 39-57. Editora UFPR, 1998.

GIORDAN, Marcelo. The role of experimentation in science education. New chemistry in school. Sao Paulo \# 10, p. 43-49, 1999.

GUIMARAES, Cleidson Carneiro. The Experimentation in Chemistry Teaching: Ways and Strayed Towards Meaningful Learning. New chemistry in school. Vol. 31, No. 3, 2009.

GÜLLICH, Roque Isamel da Costa; SILVA, Lenice Heloisa de Arruda. The trial plot in the textbook: breeding theories and scientific truths. Mato Grosso do Sul: Search test in Science Education, Vol 15, No 2, 2013.

HODSON, D. Hacia un más critical focus del trabajo de la lab. Enseñanza de las Ciencias, v. 12, No 3, p. 299-313, 1994.

LDB, Law of Directives and Bases of National Education. Brazil, in 1996.

MILK, Anna Carolina Silva; ARCHILHA, Rebeca Lopes; Carneiro, Ana Lucia Magalhaes. The science education in elementary school pcn the natural sciences and performance in the classroom a possible praxis. São Paulo, 2012.

MAIA, Juliana de Oliveira; VILLANI, Alberto. The relationship of chemistry teachers with the textbook and the teacher's notebook. São Paulo: Journal Enseñanza electronics de las Ciencias Vol 15, No. 1, p.. 121-146, 2016.

MARANDINO, Martha; SELLES, Sandra Escovedo; FERREIRA, Marcia Serra. Biology Teaching: stories and practices in different educational spaces. São Paulo, Ed. Cortez, 2009.

MARREGA, Stella. The Development and Learning of Children in kindergarten. 2014.

MAYER, Kellen Cristina Martins; SANTOS, Lucivânia Moreira; ARAUJO, José Anchieta; PAULA, Jusivania Serpa de.Dificuldades found in the discipline of natural science for elementary school students of public school in the city of redemption - PA. Education magazine spaces. Vol.3, No. 6, p. 230-241, 2013.MORTIMER, EF; CARVALHO, AMP. theoretical framework for analysis of the science teaching process. Notebook Research, n. 96, p. 5-14, 1996.

Mortimer, EF et al. curriculum proposed State of Minas Gerais Chemistry: fundamentals and assumptions. New chemical, São Paulo, v. 23, no. 2, p. 273-283, mar./abr.2000. 
NETO, José Joaquim Soares; JESUS, Girlene Ribeiro and Karino, Camila Akemi, UNB (University of Brasilia), and ANDRADE, Dalton Francisco, UFSC (Federal University of Santa Catarina): A scale to measure school infrastructure. 2013.

OLIVEIRA, Patrícia de Santos; BIRTH, Marta Cristina; BIANCONI, M. Lucia. Conceptual changes or behavioral? Science and Culture. Vol.57, N04. São Paulo, 2005.

OSSAK, Ana Lídia; Bellini, Marta. The textbook in science: teaching driver or teaching resource? Education, Health and Environment, Niterói, v.2 n.3 p. 2-22, 2009.

PEREIRA, BB experimentation in science teaching and the teacher's role in the construction of knowledge. In: Notebooks of FUCAMP, Brazil, v. 9, no. 11, 2010. Version available online at http://www.fucamp.edu.br/editora/index.php/cadernos/search/authors/view?firstName=Boscoli \& MiddleName $=$ Barbosa Pereira $\&$ lastName $=\&=$ affiliation FUCAMP $\&$ country $=$ BR Access: February 202016.

Piaget, J. Learning and knowledge. In: Piaget, J. Greco, P. Learning and knowledge. Rio de Janeiro: Freitas Bastos, 1974. Original title: Apprentissage et connaissance, 1959.

NCP, National Curriculum Parameters 1st to 4th grades - 5th to 8th grades. Ministry of Education (MEC). Brazil.

PNLD, National Textbook Program. Ministry of Education (MEC). Brazil.

ROSITO, BA Science education and experimentation. In: Constructivism and science education: epistemological and methodological reflections. Roque Moraes (Org.) - 3. Ed - Porto Alegre. EDIPUCRS, 2008.

SANTANA, Lourdes Cardoso Salette. Use and School Laboratories Management. Santa Maria: Federal University of Santa Maria, in 2011.

Santomauro, Beatriz. What Teaching of Science. New School, 219a ed. Ed.Abril, 2009.

SILVA, Diogo Tiago of .; Dornfeld, Carolina Buso. Group dynamics in biology classes: a motivational proposal for learning. Ilha Solteira, São Paulo: Journal Enseñanza electronics de las Ciencias Vol 15, No. 1, p.. 147-166, 2016.

SILVA, Weslla of Cabral. The experimentation in teaching materials of elementary school: an analysis focused on the teaching of composition of foods. Planaltina, DF: University of Brasilia, UNB Faculty Planaltina, 2014.

SUSI, Karla. Training of Science Teachers for Elementary Education. Recife, 2011.

TAHA, Marli Spat; Pinheiro, Edi Morales Jr. Learning with the investigation of experimentation in teaching science book. São Paulo: IFSP (2009)

VIEIRA, Kassius Otoni; SILVA, Rodrigo Luciano Kings; Mantovani, Harley Juliano. The development and learning in Vygotsky. Catholic University of Uberlândia.

VYGOTSKY, LS The social formation of mind. S. Paulo: Martins Fontes, 1991.

VIGOTSKI, LS; Luria AR; LEONTIEV, AN Language, development and learning. São Paulo: Icon, 1998.

WYZYKOWSKI, Tamini; Güllich, Ismael Roque da Costa; HEMEL, Erica the Holy Spirit; ARAUJO, Maria Cristina of Pansera. The trial in primary school science: a reflection on training context. Cerro Largo: 2011. 